\title{
Zmiany mikrostrukturalne w płytach skał magmowych poddanych termicznej obróbce metodą płomieniowania
}

\author{
Marek Rembiśs ${ }^{1}$, Andrzej Dubiniewicz ${ }^{1}$
}

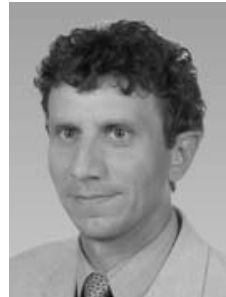

M. Rembiś

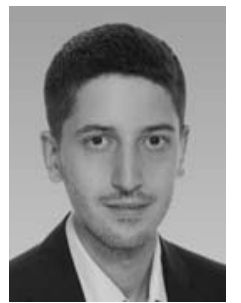

A. Dubiniewicz

Microstructural changes in flamed slabs of igneous rocks. Prz. Geol., 66: 450-456; doi: 10.7306/2018.1.

A b s t r a c t. The investigations were carried out on stone elements (slabs) cut from 11 various igneous rocks: monzogranites, a monzodiorite, granodiorites, a syenodiorite, a labradorite and a dolerite, which were next treated by flaming. In the outer zone of the slabs, the thermally affected minerals expanded and generated among themselves compressing stress phenomena; the process finally caused brittle cracking of the grains involved. As a result, some outer rock fragments have buckled and chipped off, forming surface loss defects. The size of such defects depends on two reasons: various dimensions of rock-forming minerals in the individual slabs, and non-uniform expansion of the mineral grains involved that differ in their coefficients of thermal expansion. Eventually, the defects decide on the esthetic differentiation of the slabs after flaming. In turn, the stone zones located below the reach of flaming have been affected by cracking resulting from forces of the tensile stress. The intensity and orientation of cracks within the slabs indicate that the physico-mechanical properties of the slabs after flaming may be inferior if compared with the not flamed stone slabs.

Keywords: slabs of igneous rocks, flame texture, thermal stress, brittle cracking

Płomieniowanie, zwane także wypalaniem, jest jednym ze sposobów obróbki kamienia naturalnego, dzięki któremu można uzyskać szorstką, matową powierzchnię, przypominającą wyglądem naturalny przełam. W normie PN-EN 12670: 2002 Kamień naturalny. Terminologia jest ona określana jako faktura płomieniowa. Kamienie o takiej fakturze mają szerokie zastosowanie w budownictwie, głównie jako płyty w nawierzchniach przeznaczonych do ruchu pieszego, posiadające właściwości antypoślizgowe. Zabieg płomieniowania wykonuje się przy użyciu palnika $\mathrm{z}$ mieszanką propanowo-butanową lub acetylenowa, krótkotrwale działając na powierzchnię kamienia strumieniem gorącego powietrza o temperaturze $1280-1360^{\circ} \mathrm{C}$ (Kalinowski, 2003). Zastosowanie zbyt wysokiej temperatury (powyżej $1410^{\circ} \mathrm{C}$ ) może doprowadzić do pęknięcia płyty kamiennej, natomiast działanie niższych temperatur (w zakresie $1210-1260^{\circ} \mathrm{C}$ ) wywołuje złuszczanie przypowierzchniowych partii materiału.

Anizotropia budowy wewnętrznej skały magmowej złożonej z różnych minerałów, o praktycznie dowolnym ułożeniu, powoduje, że w trakcie płomieniowania dochodzi do powstawania naprężeń termicznych o różnych wartościach i składowych stanu naprężenia zarówno w pojedynczych ziarnach, jak też pomiędzy nimi. Dla niektórych minerałów poddanych ogrzaniu charakterystyczna jest anizotropia wyrażająca się znacznym zwiększeniem długości w pewnych kierunkach, przy znikomym lub wręcz ujemnym wydłużeniu w innych. Powoduje to ich niejednorodne odkształcanie w trakcie obróbki termicznej (Cooper, Simmons, 1977). Ponadto naprężenia, a w ślad za nimi spękania, mogą tworzyć się na granicy poszczególnych ośrodków (minerałów), różniących się między sobą współczynnikami rozszerzalności cieplnej (Cooper, Simmons, 1977). Skład mineralny w dużym stopniu determinuje zatem podatność skały na obróbkę termiczną. Jednak na końcowy rezultat zabiegu płomieniowania elementu kamiennego, wyrażający się stopniem szorstkości, wielkością powstałych zagłębień, ich kształtem, rozmiarami i sposobem rozmieszczenia, wpływ ma także wielkość minerałów, ich pokrój i wzajemne relacje przestrzenne. Cechy te powodują, że ostateczny efekt wizualny płomieniowanej powierzchni jest czasem trudny do przewidzenia. Oprócz wyglądu zewnętrznego uzyskanej faktury, istotne znaczenie ma także stan zachowania elementu kamiennego poddanego takiej dość radykalnej obróbce termicznej. Jego oceny można dokonać poprzez określenie zmiany wartości właściwości fizyczno-mechanicznych kamienia w stosunku do stanu przed jego płomieniowaniem oraz charakterystykę zachodzących zmian mikrostrukturalnych, które w dużym stopniu determinują parametry techniczne. Oba rodzaje badań pozwalają określić, czy obróbka termiczna kamienia została wykonana poprawnie i czy element kamienny będzie posiadał wystarczające właściwości użytkowe i tym samym spełni wymagania podstawowe stawiane wyrobom budowlanym. W niniejszej pracy dokonano oceny zmian mikrostrukturalnych powstałych w płomieniowanych płytach kamiennych, wykonanych z różnych skał magmowych. Charakterystyka zmian ich fizyczno-mechanicznych właściwości stanowi natomiast przedmiot oddzielnych badań.

\section{METODYKA BADAŃ}

Jako przedmiot badań wybrano różnorodne skały magmowe powszechnie stosowane w budownictwie. Są to granity o komercyjnych nazwach: Strzegom z Polski, Baltic Brown z Finlandii, Padang Dark, Grey Super Dark, Sunny Desert, Queen Yellow, G603 i Queen Brown z Chin, a także

\footnotetext{
${ }^{1}$ AGH Akademia Górniczo-Hutnicza im. S. Staszica w Krakowie, Wydział Geologii, Geofizyki i Ochrony Środowiska, al. A. Mickiewicza 30,30-059 Kraków; mrembis@geol.agh.edu.pl; dubiniewiczandrzej@gmail.com.
} 
doleryt Reko-Black i labradoryt Volga Blue z Ukrainy oraz monzodioryt Indian Black z Indii.

Próbki do badań w postaci płyt kamiennych pochodziły z zakładów kamieniarskich, gdzie jedna z ich powierzchni została poddana obróbce termicznej metodą płomieniowania.

Ocenę rodzaju zmian mikrostrukturalnych skał wykonano za pomocą skaningowego mikroskopu elektronowego NOVA NANO SEM firmy FEI Company, badając próbki pobrane z powierzchni niepłomieniowanych i płomieniowanych. Dodatkowo, wykorzystując system optyczny mikrotwardościomierza Knoopa/Vickersa (model HVKD-1000 IS), wykonano obserwacje w świetle odbitym, przy powiększeniu 400X dużych obszarów obu powierzchni płyt. Ponadto, z każdego badanego elementu kamiennego wykonano preparaty do badań mikroskopowych w świetle przechodzącym, na których, przy użyciu polaryzacyjnego mikroskopu optycznego do światła przechodzącego typu JENAPOL (Carl Zeiss Jena), obserwowano cechy strukturalne kamienia w przekroju poprzecznym płyty. Równocześnie wykonano podstawowy opis petrograficzny badanych skał, określając ich nazwy zgodnie z klasyfikacją IUGS.

\section{CHARAKTERYSTYKA LITOLOGICZNA SKAL}

\section{Granit Strzegom}

Skała pochodzi z waryscyjskiego Masywu Strzegomia-Sobótki, zlokalizowanego na Przedgórzu Sudeckim w południowo-zachodniej części Polski. Ma jasnoszarą barwę, teksturę nierównokrystaliczną, subhedralnoziarnistą. W składzie mineralnym jest obecny kwarc, stanowiący $26,09 \%$ obj. o rozmiarach ziaren $1,08-2,32 \mathrm{~mm}$. W podobnym udziale (26,08\% obj.) stwierdzono plagioklazy o wielkości $0,76-4,80 \mathrm{~mm}$. Ponadto, w kilkuprocentowych udziałach występują skalenie potasowe o rozmiarach 0,84-4,84 $\mathrm{mm}$ i biotyt $(0,68$ do $0,88 \mathrm{~mm})$ oraz podrzędnie allanit, minerały rudne, hornblenda, tytanit, cyrkon, apatyt i epidot. Petrograficznie badana skała jest monzogranitem.

\section{Granit Baltic Brown}

Granit powstał w czasie orogenezy karelskiej i genetycznie jest związany z wielką intruzją magmową, określaną jako batolit Wyborga (Harma i in., 2014). Eksploatowany jest w okolicach miasta Ylämaa w Karelii Południowej (Finlandia). Skała ma różowo-szaro-zieloną barwę. Posiada klasyczną teksturę rapakiwi. Głównym jej składnikiem są porfirokryształy skaleni potasowych obecne w udziale $43,37 \%$ obj. Osiagają one rozmiary od 1,20 do $26,0 \mathrm{~mm}$. Otoczone są cienkimi obwódkami z plagioklazu, którego udział wynosi 16,85\% obj. Dość licznie (25,09\% obj.) występuje kwarc o rozmiarach $0,44-3,60 \mathrm{~mm}$. W udziale $5,73 \%$ obj. jest obecny biotyt $(0,52$ do $2,56 \mathrm{~mm})$. W podrzędnych ilościach występują: hornblenda, minerały rudne oraz cyrkon. Składniki mineralne są wykształcone anhedralnie, rzadziej subhedralnie. Omawiana skała jest syenodiorytem, będąc jednocześnie szczególną odmianą granitu rapakiwi o lokalnej nazwie - wyborgit.

\section{Doleryt Reko-Black}

Skała jest eksploatowana niedaleko wsi Bazaltove, zlokalizowanej na północ od miasta Rivne na Ukrainie. Doleryty, określane także jako bazalty Ivano-Dolynske, tworzą wraz z przewarstwiającymi je tufami wołyńską serię wulkanogeniczną wieku wendyjskiego (Bobrov i in., 2002). Barwa skały jest czarna, a tekstura drobnokrystaliczna, ofitowa. Zbudowana jest z plagioklazów obecnych w udziale $30,92 \%$ obj. i wielkości $0,88-2,60 \mathrm{~mm}$, ponadto z piroksenów, stanowiących $31,73 \%$ obj. i rozmiarach od 0,96 do $2,08 \mathrm{~mm}$, a także oliwinów występujących w udziale $16,87 \%$ obj. i wielkości od 0,24 do 1,20 mm. Pomiędzy tymi składnikami występuje tło skalne składające się z trudno identyfikowalnych ziaren plagioklazów i piroksenów, które są poprzerastane igiełkowato wykształconymi minerałami rudnymi.

\section{Labradoryt Volga Blue}

Skała występuje w środkowoproterozoicznym masywie wołodarskim, będącym częścią plutonu korosteńskiego (Kravchenko, 2005). Eksploatowana jest w obwodzie żytomierskim, znajdującym się w północnej części Ukrainy. Badana skała jest grubokrystaliczna i posiada czarno-zielonkawą barwę. Składa się niemal wyłącznie (83,14\% obj.) z euhedralnych ziaren plagioklazów. Osiaggają one wielkość dochodzącą do 47,0 mm. Oprócz nich, w udziale 7,25\% obj., występują pirokseny o wielkościach od 0,38 do 5,08 mm. Podrzędnie obecne są kwarc, biotyt, hornblenda i minerały rudne.

\section{Granity Padang Dark, Grey Super Dark, Sunny Desert, Queen Yellow, G603 i Queen Brown}

Skały te pochodzą z prowincji Fujian w południowo-wschodnich Chinach. Granity Padang Dark i Grey Super Dark są wydobywane niedaleko miasta Changle, natomiast Sunny Desert i Yellow Queen z kamieniołomów w rejonie Shijing. Granit G603 pochodzi z okolic Jinjiang, zaś Queen Brown jest eksploatowany niedaleko miejscowości Luodong. Złoża tych skał reprezentują rozległe, intruzywne kompleksy wulkaniczne wieku kredowego, powstałe w strefie subdukcji płyty pacyficznej pod płytę euroazjatycką (Zhao i in., 2015).

Granity Padang Dark i Grey Super Dark posiadają ciemnoszarą barwę, a ich tekstura jest nierównokrystaliczna (od drobno- do średniokrystalicznej), subhedralna. W obu skałach dominującym składnikiem są plagioklazy. W pierwszej z nich stanowią one $31,4 \%$ obj. i posiadają wielkość 0,38-2,05 mm, w drugiej - 41,85\% obj., przy zmienności rozmiarów od 0,19 do $2,40 \mathrm{~mm}$. Ponadto w składzie mineralnym występuje kwarc, który w granicie Padang Dark stanowi $24,47 \%$ obj. a jego ziarna mają wielkość $0,93-$ $2,62 \mathrm{~mm}$. W drugim z granitów, udział kwarcu wynosi $23,69 \%$ obj. a jego rozmiary wahają się w granicach od 0,38 do $1,95 \mathrm{~mm}$. W kilkuprocentowych udziałach są obecne skalenie potasowe, biotyt, pirokseny oraz amfibole. Podrzędnie pojawiają się minerały rudne oraz epidot. Zgodnie z klasyfikacją IUGS obie skały są granodiorytami biotytowymi.

Granity Sunny Desert i Queen Yellow posiadają zielonkawo-żółtą barwę, a ich tekstura jest średniokrystaliczna, subhedralna. Złożone są z kwarcu o rozmiarach ziaren 0,29-5,60 mm. Jego udział w odmianie Sunny Desert wynosi 32,19\% obj., natomiast w Queen Yellow - 21,74\% obj. Udział plagioklazów w obu skałach wynosi kolejno 31,43 i $38,64 \%$ obj., natomiast skalenie potasowe są obecne w udziale 31,42 i 35,75\% obj. Wielkość ich ziaren jest podob- 
na i wynosi od 0,44 do $3,58 \mathrm{~mm}$. W kilkuprocentowych udziałach jest obecny biotyt, a podrzędnie także minerały rudne, monacyt i tytanit. Badane skały są monzogranitami.

Granit G603 jest jasnoszarą skałą, o średniokrystalicznej, subhedralnej teksturze. Jego głównym składnikiem są plagioklazy, obecne w udziale 33,9\% obj. Posiadają one zróżnicowane rozmiary w zakresie $0,93-3,07 \mathrm{~mm}$. Występuje również kwarc, stanowiący $26,03 \%$ obj., i biotyt (udział 12,33\% obj.). Wielkość tych minerałów nie przekracza $1,76 \mathrm{~mm}$. W niewielkiej ilości występują skalenie potasowe, minerały rudne, tytanit, anortoklaz i muskowit. Petrograficznie jest to monzogranit biotytowy.

Granit Queen Brown charakteryzuje się brązową barwą. Ma średniokrystaliczną, subhedralną teksturę. Głównym składnikiem są plagioklazy obecne w udziale 33,66\% obj., o zmiennych rozmiarach w zakresie $0,58-3,33 \mathrm{~mm}$. Ponadto w ilości $26,24 \%$ obj. występują skalenie potasowe, które osiagają wielkość do $3,68 \mathrm{~mm}$, oraz kwarc w udziale $23,27 \%$ obj. i rozmiarach 1,02-2,53 mm. Skład mineralny uzupełnia biotyt, hornblenda oraz minerały rudne i tytanit. Omawiana skała jest monzogranitem.

\section{Monzodioryt Indian Black}

Skała jest wydobywana na południu Indii, w rejonie Chamarajanagar (stan Karnataka). Pochodzi z jednej z licznych, późnoarchaicznych intruzji magmowych powstałych w obrębie kratonu Karnataka (Misra, 2012). Badana skała ma czarną barwę oraz drobnokrystaliczną, euhedralną teksturę. Zbudowana jest z plagioklazów obecnych w udziale $31,91 \%$ obj. i wielkości $0,42-2,02 \mathrm{~mm}$ oraz piroksenów stanowiących $31,12 \%$ obj. i rozmiarach $0,32-2,40 \mathrm{~mm}$. Dość liczny (14,01\% obj.) jest nefelin o kryształach wielkości poniżej 1,98 mm. Pozostałą część stanowią skalenie potasowe, minerały rudne, biotyt oraz sporadycznie występujący apatyt i uralit. Omawianą skałę zaklasyfikowano jako monzodioryt foidowy.

\section{ZMIANY STRUKTURALNE KAMIENI WYWOLANE PLOMIENIOWANIEM}

W nagrzewanym fragmencie skały, ze względu na niskie przewodnictwo cieplne i wysokie ciepło właściwe minerałów, wysoka temperatura wywołuje wydłużenie liniowe minerałów. Według Germanovicha (1997) oraz Deeny i in. (2009) powoduje to powstawanie naprężeń ściskających w obrębie cienkiej warstwy w pobliżu ogrzanej powierzchni oraz tworzenie się naprężeń rozciągających w chłodniejszym wnętrzu. Pod wpływem działających naprężeń w składnikach mineralnych powstają mikrospękania, wywołane wzrostem ich objętości, a następnie dochodzi do odpryskiwania i wykruszania ich fragmentów (Rauenzahn, Tester, 1989). Procesowi temu szczególnie łatwo ulega kwarc i z tego względu początkowo płomieniowano wyłącznie granity. Obecnie uważa się, że takiej obróbce można poddać każdą skałę zawierającą w swoim składzie mineralnym kwarc i/lub krzemionkę (Kalinowski, 2003). Dlatego, oprócz typowych granitów, wypala się także inne skały magmowe, takie jak: sjenity, dioryty, a nawet bazalty, ponadto niektóre skały metamorficzne (gnejsy i kwarcyty) i skały osadowe (piaskowce).

Naprężenia termiczne pojawiające się w rozgrzanej skale są wywołane nierównomiernym rozszerzaniem się poszczególnych ziaren mineralnych. Uwzględniając jedy- nie rozszerzalność liniową, naprężenia te są zależne od iloczynu wartości współczynnika cieplnej rozszerzalności liniowej, modułu sprężystości podłużnej minerałów oraz gradientu działającej temperatury (Majcherczyk, 1989). Ponieważ jednak zmiany rozmiarów ziaren zachodzą w przestrzeni trójwymiarowej, wartość naprężeń termicznych jest wyrażona wzorem:

$$
\sigma_{T}=\kappa \cdot \omega \cdot \Delta \mathrm{T}=\frac{E \cdot \omega \cdot \Delta T}{3(1-v)}
$$

$\left[\mathrm{N} / \mathrm{m}^{2}\right]$

gdzie:

$\kappa$ - moduł sprężystości objętościowej,

$\omega$ - współczynnik cieplnej rozszerzalności objętościowej,

$\Delta T$ - przyrost temperatury,

$E$ - moduł sprężystości podłużnej,

$v$ - liczba Poissona.

Wśród minerałów skałotwórczych szczególnie wrażliwy na zmiany termiczne jest kwarc. Jak podaje Kowalski (2004), podczas przemiany $\alpha$-kwarcu w $\alpha$-trydymit następuje wydłużenie liniowe kryształu o prawie 14\%. Według Robertsona (1988), w temperaturze $20-400{ }^{\circ} \mathrm{C}$ kwarc posiada stosunkowo wysoki współczynnik cieplnej rozszerzalności objętościowej $(\omega)$ równy $4,98 \cdot 10^{-5} \mathrm{~K}^{-1}$. Nieco niższe wartości wykazuje hornblenda $\left(2,56 \cdot 10^{-5} \mathrm{~K}^{-1}\right)$ (Huotari, Kukkonen, 2004) oraz albit $\left(2,24 \cdot 10^{-5} \mathrm{~K}^{-1}\right) \mathrm{i}$ augit $\left(2,19 \cdot 10^{-5} \mathrm{~K}^{-1}\right)$, natomiast dla ortoklazu jest ona równa $1,54 \cdot 10^{-5} \mathrm{~K}^{-1}$, a dla anortytu tylko $1,51 \cdot 10^{-5} \mathrm{~K}^{-1}$ (Robertson, 1988).

Wykonane w ramach niniejszej pracy badania wykazały, że w wyniku zabiegu płomieniowania omawiane skały magmowe uzyskały fakturę o zróżnicowanej morfologii. Najbardziej jednorodną powierzchnię o niewielkiej szorstkości otrzymano w drobnokrystalicznych skałach: granodiorycie Grey Super Dark i monzodiorycie Indian Black (ryc. 1). Zagłębienia obserwowane na powierzchni płyt są płytkie, równomiernie rozmieszczone i o niewielkich rozmiarach, rzędu $15 \mathrm{~mm}^{2}$. Związane są one $\mathrm{z}$ obecnością ubytków, widocznych głównie w ziarnach kwarcu, w mniejszym zakresie w plagioklazach, a tylko sporadycznie w minerałach ciemnych. W monzodiorycie ubytki stwierdzono przede wszystkim w skaleniach i skaleniowcach.

W granitach: G603, Sunny Desert, Strzegom i Queen Brown powierzchnia płyt jest bardziej szorstka. Zagłębienia mają wyraźnie większą powierzchnię (do ok. $25 \mathrm{~mm}^{2}$ ), co wynika $\mathrm{z}$ większych rozmiarów ziaren budujących te skały. Ubytki o największej głębokości są obecne w kwar$\mathrm{cu}$, natomiast nieco płytsze występują w skaleniach. Minerały ciemne uległy znikomemu wykruszeniu podczas płomieniowania i stanowią elementy wypukłe na powierzchni, wyraźnie wystając powyżej pozostałych składników (ryc. 2). Spośród tych skał największą amplitudę ubytków, a tym samym największą szorstkość powierzchni, stwierdzono w granicie Queen Brown.

W dolerycie Reko Black, mimo że zagłębienia związane z wykruszeniem fragmentów ziaren są rozległe (do ok. $30 \mathrm{~mm}^{2}$ ), to jednak są dość płytkie. Utworzyły się one głównie w skaleniach, a na mniejszą skalę w piroksenach i oliwinach.

W labradorycie Volga Blue ziarna skaleni są wyraźnie spękane, a ich duże fragmenty, o znacznych rozmiarach osiągających wielkość ok. $120 \mathrm{~mm}^{2}$, uległy wykruszeniu. $\mathrm{W}$ efekcie, powierzchnia płomieniowana jest zadziorowata, 
o prostokątnych lub drzazgowatych ubytkach o zróżnicowanej głębokości, wykazując tym samym stosunkowo niskie walory dekoracyjne (ryc. 3).

W granicie Baltic Brown destrukcji związanej z działaniem wysokiej temperatury uległy głównie ziarna kwarcu, w których są zauważalne wyraźne odpryski. Duże ubytki występują także w obwódkach plagioklazowych, rozwiniętych na skaleniach potasowych. Te ostatnie, mimo że są znacznie spękane, stanowią w morfologii powierzchni płyty formy wyraźnie wypukłe, o okrągłych lub owalnych kształtach i powierzchniach dochodzących do $200 \mathrm{~mm}^{2}$.

Obserwacje mikroskopowe wykazały, że opisane powyżej ubytki powstały wskutek odspojenia fragmentów minerałów zachodzącego wzdłuż płaszczyzn spękań, jakie rozwinęły się na ich ziarnach, a które nie są obecne w

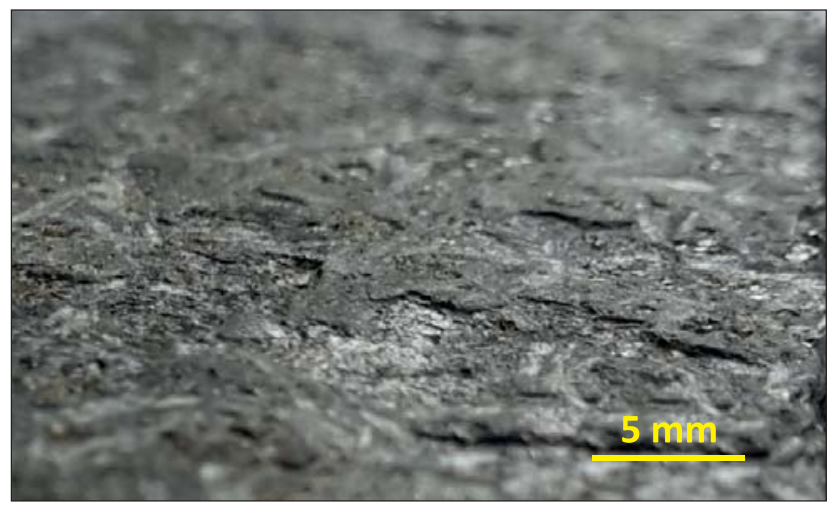

Ryc. 1. Powierzchnia płomieniowana granodiorytu Grey Super Dark

Fig. 1. The flamed surface of the Grey Super Dark granodiorite

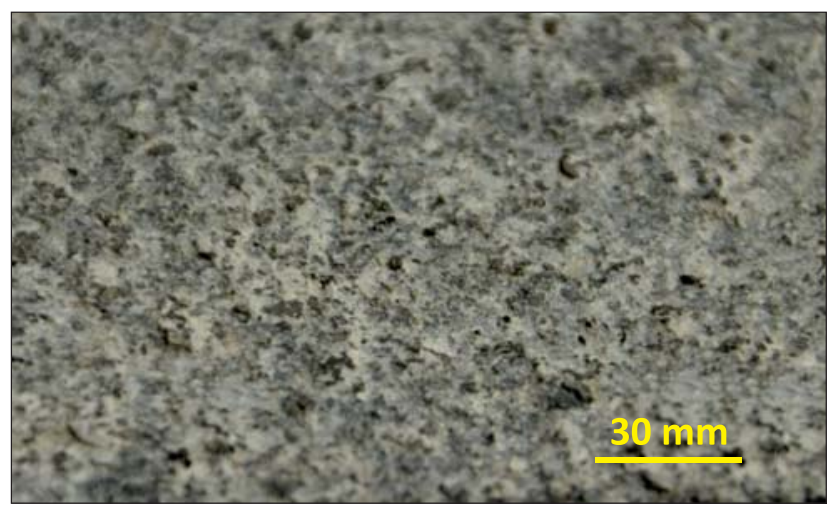

Ryc. 2. Powierzchnia płomieniowana granitu G603

Fig. 2. The flamed surface of the G603 granite

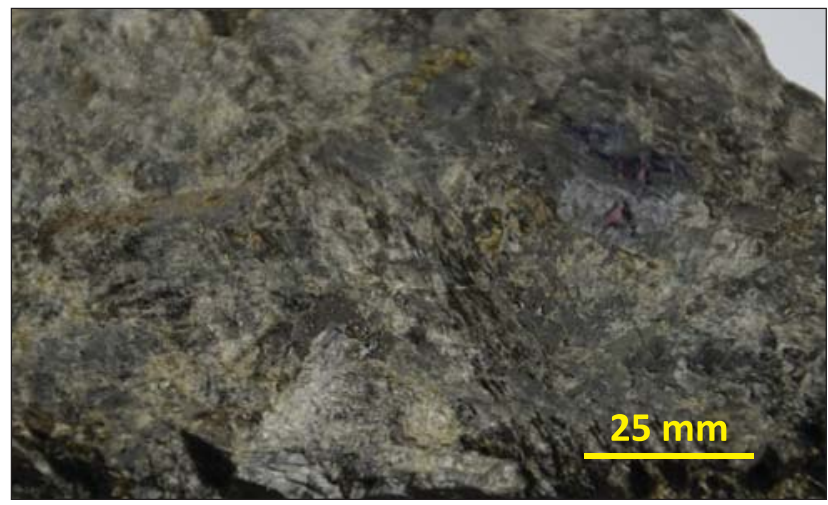

Ryc. 3. Powierzchnia płomieniowana labradorytu Volga Blue Fig. 3. The flamed surface of the Volga Blue labradorite głębszych partiach kamienia. Na górnych powierzchniach ziaren skaleni, piroksenów i amfiboli, poddanych bezpośredniemu nagrzewaniu, stwierdzono obecność rozgałęziających się spękań (ryc. 4) typu dorzecza (river pattern). Są one typowe dla kruchego pękania zginanych ziaren w wyniku ich ściskania. Powstają wówczas, gdy różne części pęknięcia rozprzestrzeniają się na równoległych płaszczyznach krystalograficznych, łącząc się w kierunku czoła pęknięcia, czyli w kierunku jego propagacji (Staroselsky i in., 1990; Staroselsky, 2005). Na ziarnach kwarcu, pęknięcia tego rodzaju są mniej czytelne i często wyraźnie ugięte, o falistym, „muszlowym” układzie (ryc. 5). Odmienne przejawy deformacji, w postaci równoległych prążków, stwierdzono natomiast na powierzchni skupień tlenków i wodorotlenków żelaza obecnych w granicie Sunny Desert (ryc. 6). Tego rodzaju formy są powszechnie obserwowane w metalach poddawanych obciążeniom i interpretowane jako przejawy cyklicznego, zmęczeniowego odkształcenia plastycznego (Staroselsky, 2005).

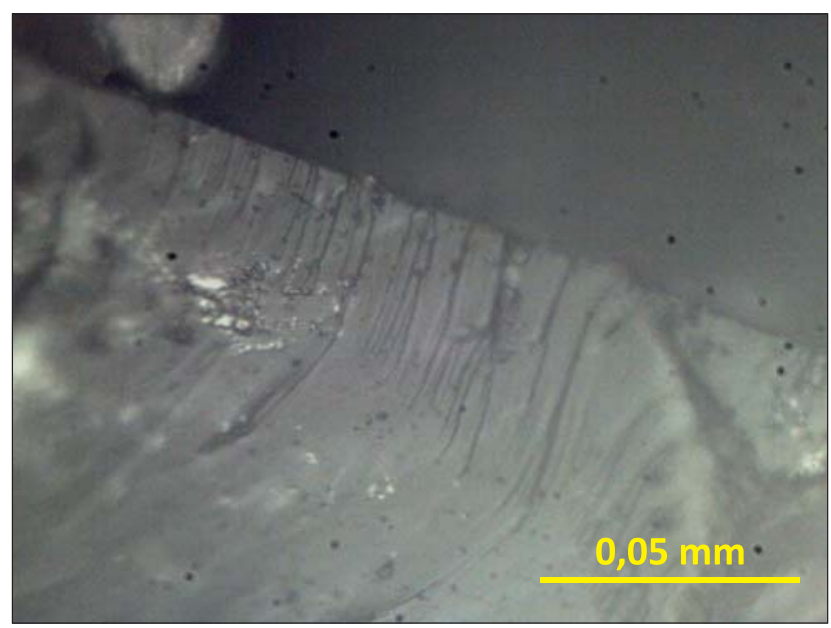

Ryc. 4. System rozgałęziających się spękań typu dorzecza w ziarnie plagioklazu. Obraz mikroskopowy w świetle odbitym powierzchni płomieniowanej monzogranitu Queen Yellow

Fig. 4. The network of branching off river pattern cracks within a plagioclase grain. Microscopic view in the transmitted light of the flamed surface of the Queen Yellow monzogranite

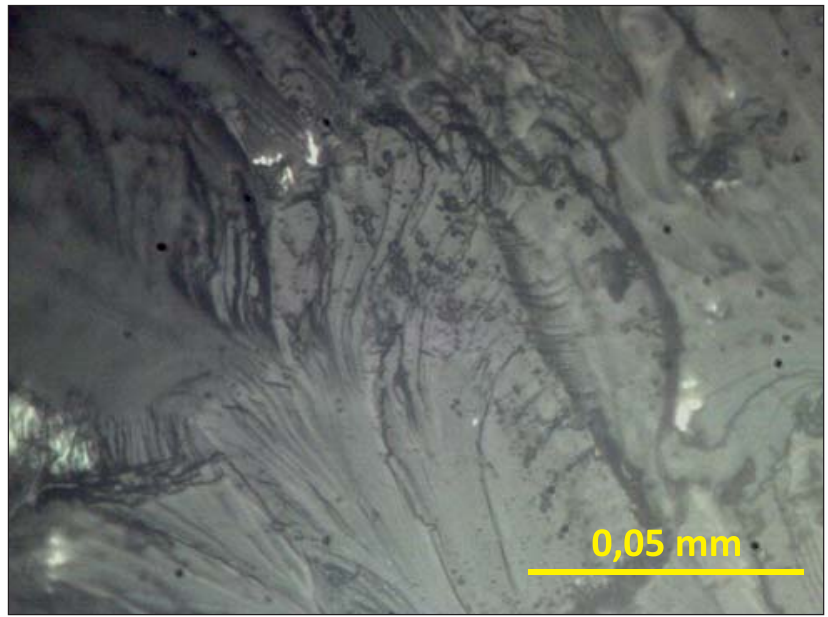

Ryc. 5. Spękania typu dorzecza rozwinięte w ziarnie kwarcu. Obraz mikroskopowy w świetle odbitym powierzchni płomieniowanej monzogranitu Strzegom

Fig. 5. The network of branching off river pattern cracks within a quartz grain. Microscopic view in the transmitted light of the flamed surface of the Strzegom monzogranite 
Obserwacje powierzchni przekroju płyt wykazały, że przejawy kruchego pękania zaznaczają się także w ich strefie przypowierzchniowej, natomiast jest ich brak w niższych częściach kamienia. Grubość strefy zawierającej takie spękania w labradorycie Volga Blue wynosi ok. $8 \mathrm{~mm}$, w granitach dochodzi do ok. $2 \mathrm{~mm}$, a w granodiorycie Grey Super Dark, monzodiorycie Indian Black oraz dolerycie Reko Black nie przekracza 0,3 mm. Najbardziej wyraźne są spękania o ułożeniu równoległym do powierzchni płyty i o długości odpowiadającej sumie średnic kilku ziaren (ryc. 7). W niektórych skaleniach są to dwie lub trzy linie spękań, równoległe względem siebie. We wszystkich obserwowanych miejscach głębokość ich położenia względem górnej powierzchni płyty jest mniejsza niż średnica

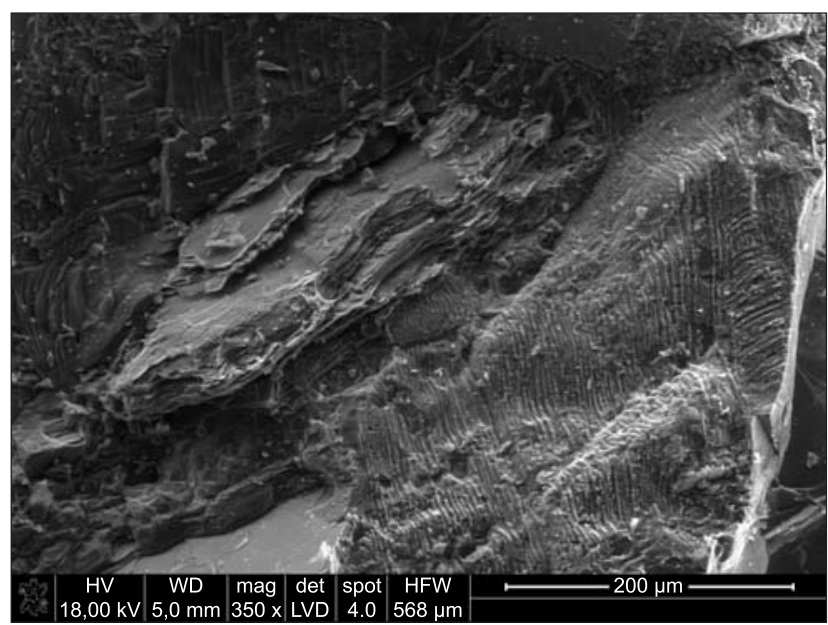

Ryc. 6. Prążkowanie (prawa część fotografii) powstałe w wyniku zmęczeniowego odkształcenia plastycznego, obecne na powierzchni skupienia wodorotlenków żelaza. Obraz SEM płomieniowanej powierzchni granitu Sunny Desert

Fig. 6. Striation (right side of the image) of the fatigue plastic deformation, present on the surface of iron oxyhydroxide accumulation. SEM microimage of the flamed surface of the Sunny Desert granite

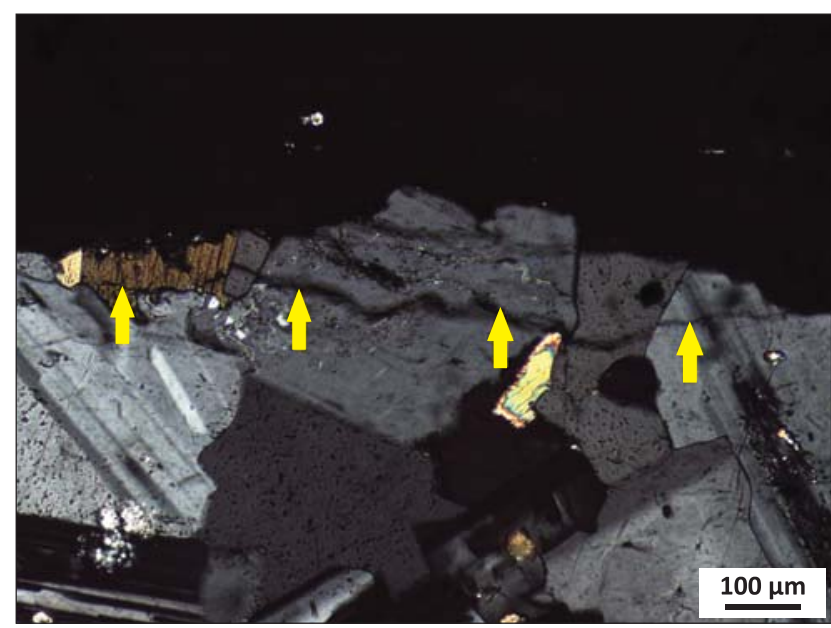

Ryc. 7. Spękanie (strzałki) o przebiegu równoległym do powierzchni płyty, wywołane naprężeniami ściskającymi. Mikrofotografia w świetle przechodzącym (polaryzatory skrzyżowane) przekroju płyty (w strefie przypowierzchniowej) granodiorytu Grey Super Dark

Fig. 7. Cracks (arrows) induced by the compressive stress and developed parallel to the slab surface. Microscopic view in the transmitted light (crossed polarizers) of a near-surface cross-section of the Grey Super Dark granodiorite slab ziaren, przez które biegną. Taki sam charakter spękań wywołanych naprężeniami ściskającymi wykazali dla granitów badaniami eksperymentalnymi Rauenzahn i Tester (1989), a mechanizm ich powstawania omówili na podstawie badań modelowych Walsh i in. (2011). Omawiane spękania mają swój początek w miejscach stykania się ziaren, a następnie rozprzestrzeniają się wzdłuż granic pomiędzy ziarnami oraz wewnątrz nich. Można na tej podstawie wnioskować, że granice międzyziarnowe, w których zachodzi inicjacja spękań, są strefami najbardziej podatnymi na destrukcję wywołaną powstającymi naprężeniami. Spękania o takim, w przybliżeniu równoległym do powierzchni kamienia przebiegu przecinają ziarna mineralne zazwyczaj w sposób nieregularny, tylko miejscami wykorzystując płaszczyzny ich łupliwości. Jak wykazały wyniki badań wspomnianych autorów, kierunek propagacji pęknięcia jest w dużej mierze zależny od kierunku miejscowego naprężenia ściskającego. $\mathrm{Na}$ działanie takiego rodzaju naprężenia, równoległego do powierzchni zewnętrznej kamienia, wskazuje także charakterystyczna, ząbkowana linia spękania biegnącego skośnie względem powierzchni kamienia (ryc. 8). Tego rodzaju nieciągłość określana jest jako quasi planarne, zewnętrzne pęknięcie wtórne. Zazwyczaj nachylone jest ono pod kątem ok. $45^{\circ}$ w stosunku do kierunku siły ściskającej (Sagong, Bobet, 2002). W omawianej strefie przypowierzchniowej są także obecne spękania ułożone poprzecznie w stosunku do powierzchni płyt (ryc. 9). Mają one najprawdopodobniej charakter spękań przegubowych, ,katetalnych”, rozwijających się w najbardziej zewnętrznych fragmentach skały, poddanych zginaniu. Są one szczególnie wyraźnie widoczne w labradorycie Volga Blue oraz granicie Baltic Brown, charakteryzujących się grubokrystaliczną teksturą, a także w nierównokrystalicznym granicie Strzegom.

W głębszej części płyt, bardziej oddalonej od płomieniowanej powierzchni, spękania są mniej liczne i są rozwinięte jedynie w pojedynczych ziarnach, nie wykazując kontynuacji na powierzchni sąsiednich minerałów. W kwarcu mają one nieregularny przebieg, natomiast w skaleniach,

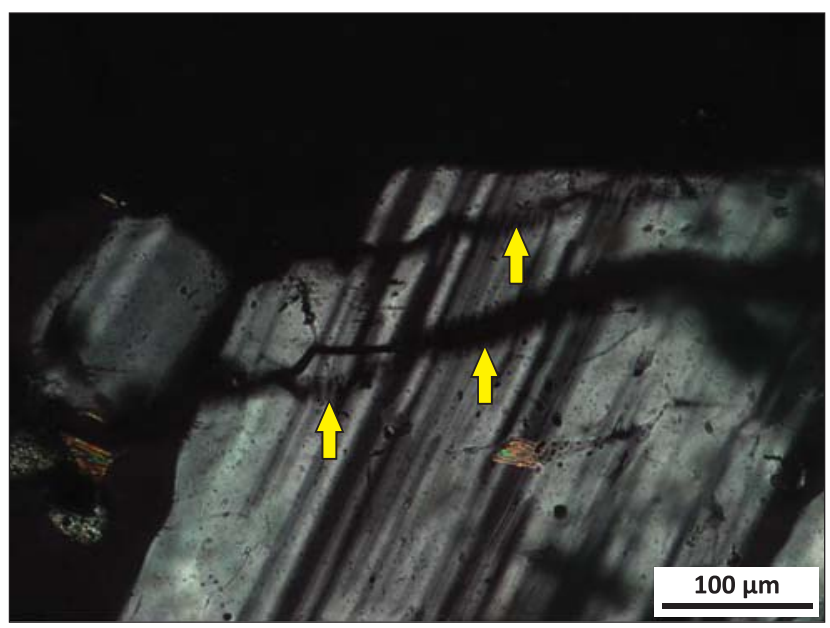

Ryc. 8. Ząbkowane linie zewnętrznych spękań wtórnych (strzałki) o przebiegu skośnym względem kierunku działania siły ściskającej. Mikrofotografia w świetle przechodzącym (polaryzatory skrzyżowane) przekroju płyty (w strefie przypowierzchniowej) labradorytu Volga Blue

Fig. 8. The lines of serrated secondary cracks (arrows) diagonal to the direction of the compressive stress. Microscopic view in the transmitted light (crossed polarizers) of a near surface cross-section of the Volga Blue labradorite slab 


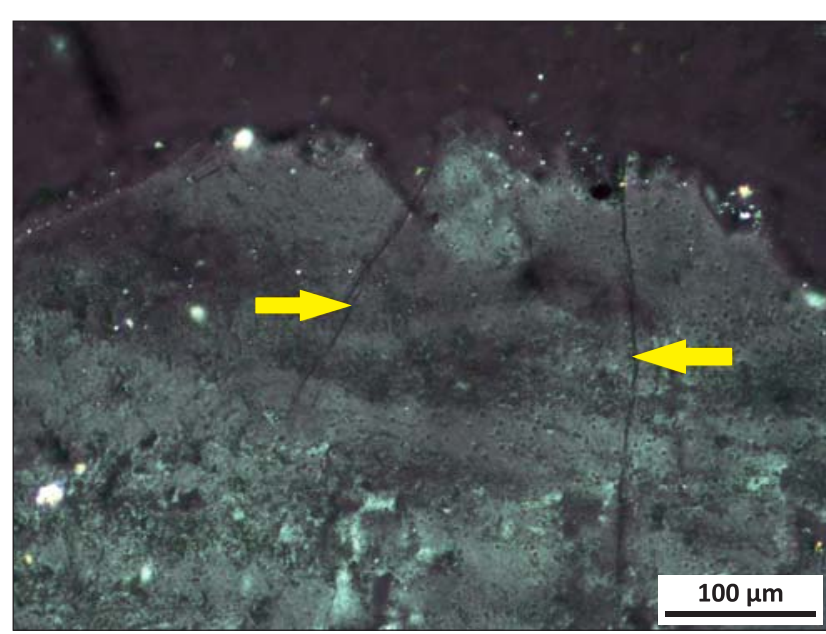

Ryc. 9. Spękania przegubowe w ziarnie skalenia (strzałki), obecne w zewnętrznej części płyty, którą poddano naprężeniom zginającym. Mikrofotografia w świetle przechodzącym (polaryzatory skrzyżowane) przekroju płyty monzogranitu Strzegom

Fig. 9. Tension cracks within a feldspar grain (arrows) present in the outer part of the slab exposed to the bending stress. Microscopic view in the transmitted light (crossed polarizers) of a cross section of the Strzegom monzogranite slab

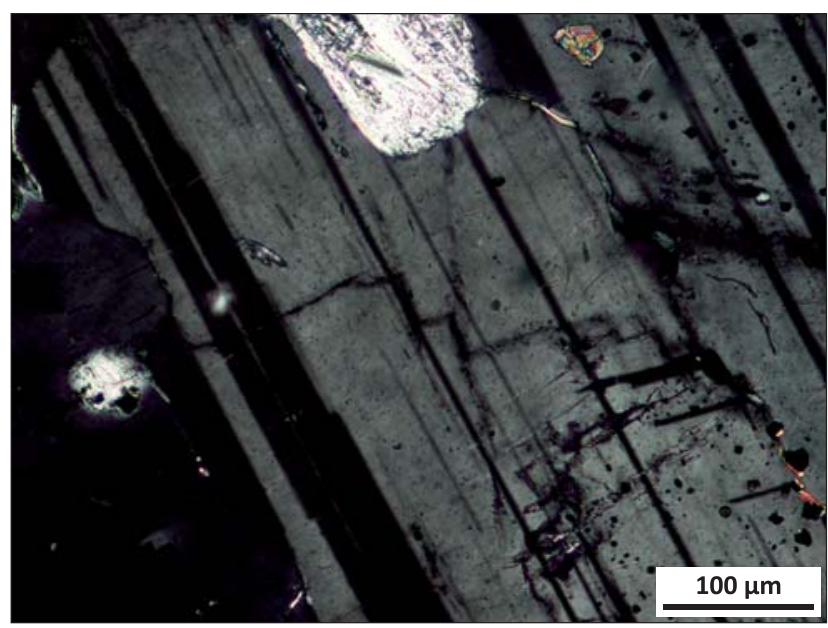

Ryc. 10. Spękanie rozwinięte wzdłuż krawędzi łupliwości plagioklazu powstałe w wyniku działania naprężeń rozciaggających. Mikrofotografia w świetle przechodzącym (polaryzatory skrzyżowane) przekroju płyty granodiorytu Grey Super Dark

Fig. 10. Cracks developed within the cleavage plane of a plagioclase grain due to the tension stress. Microscopic view in the transmitted light (crossed polarizers) of a cross-section of the Grey Super Dark granodiorite slab

piroksenach i amfibolach są rozwinięte wzdłuż krawędzi łupliwości (ryc. 10). Ich powstanie jest najprawdopodobniej związane z działaniem naprężeń rozciągających, które istnieją w strefie chłodniejszej, niepoddanej bezpośredniemu działaniu wysokiej temperatury (Homand-Etienne, Houpert, 1989). Ilość tych spękań jest zauważalnie większa niż stwierdzono to $\mathrm{w}$ najniższej części wszystkich badanych płyt, gdzie są one zupełnie sporadyczne.

\section{PODSUMOWANIE}

W trakcie płomieniowania w zewnętrznej strefie płyt kamiennych doszło do powstania naprężeń ściskających, wywołanych zwiększaniem objętości rozgrzewanych minerałów i generowania w nich kruchych spękań. Wywołało

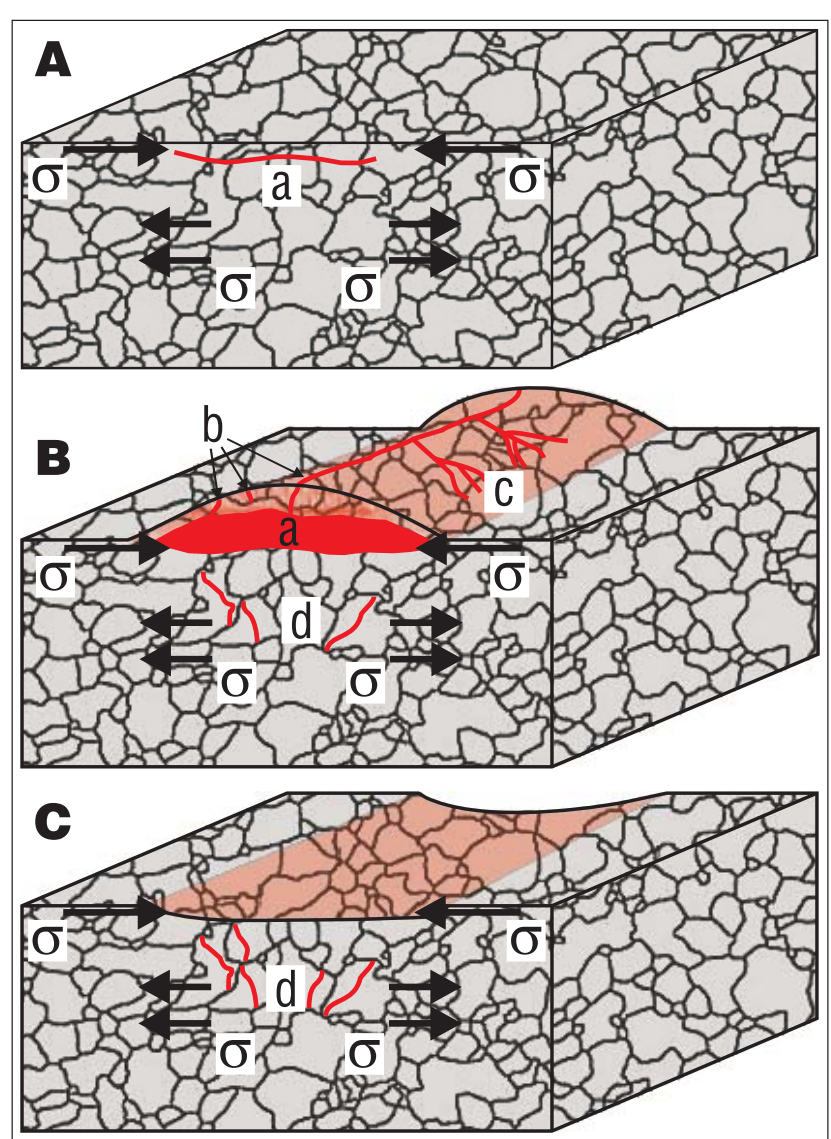

Ryc. 11. Schemat powstawania ubytku na płomieniowanej powierzchni kamienia. A - powstawanie przypowierzchniowych spękań poziomych, B - wyboczenie powierzchni, $\mathbf{C}$ - odpryśnięcie okruchu i powstanie ubytku; $\sigma$ - naprężenia ściskające i rozciągające, a - spękania poziome kompresyjne, b - spękania przegubowe, c - spękania typu dorzecza, $\mathrm{d}$ - spękania tensyjne

Fig. 11. Formation of a loss defect on the surface of the flamed stone - the schematic diagram. A - development of near-surface horizontal cracks, $\mathbf{B}$ - buckling of the rock surface, $\mathbf{C}$ - a rock fragment chips off with giving rise to a loss defect; $\sigma$ - compressing and tensile stress directions, a - horizontal compressive cracks, $\mathrm{b}$ - tension cracks, $\mathrm{c}$ - river pattern cracks, $\mathrm{d}-$ tensile cracks

to wyginanie ku górze fragmentów skał, a następnie ich odspajanie wg schematu przedstawionego na rycinie 11 . W wyniku tych procesów, na powierzchni płyt powstały ubytki o grubości mniejszej niż przeciętna wielkość ziaren w skale i kilkukrotnie większej długości. Ich wielkość, decydująca o wizualnym zróżnicowaniu efektu płomieniowania, jest więc związana $\mathrm{z}$ rozmiarem składników poszczególnych skał. Tym bardziej, że jak wykazały badania Walsha $\mathrm{i}$ in. (2011) rozkład temperatury w rozgrzewanych powierzchniowo skałach drobnokrystalicznych jest bardziej równomierny niż w skałach polimineralnych, grubiej krystalicznych. W związku z tym zespoły mniejszych ziaren ulegają odpryskiwaniu trudniej niż te, które zawierają większe składniki. Wśród badanych skał fakturę najbardziej jednorodną i jednocześnie atrakcyjną wizualnie uzyskały odmiany drobnokrystaliczne: granodioryt Grey Super Dark i monzodioryt Indian Black, natomiast znaczną nieregularność powierzchni wykazał grubokrystaliczny labradoryt Volga Blue i granit Baltic Brown zawierający porfirokryształy skaleni.

Różna podatność minerałów na działanie wysokiej temperatury wyrażona wartością współczynnika cieplnej rozszerzalności objętościowej $(\omega)$ spowodowała, że w 
badanych skałach, zawierających minerały o podobnych wartościach tego parametru, odpryskiwanie powierzchniowych fragmentów płyty zachodzi znacznie trudniej niż w skałach, w których te różnice są wyraźne. Pierwsza sytuacja ma miejsce w dolerycie Reko-Black i monzodiorycie Indian Black, złożonych $\mathrm{z}$ minerałów o wartości współczynnika $\omega \mathrm{w}$ zakresie $2,19-2,84 \cdot 10^{-5} \mathrm{~K}^{-1}$ oraz $\mathrm{w}$ niemal monomineralnym labradorycie Volga Blue, zawierającym głównie plagioklazy o wartości $\omega$ wynoszącej ok. $2,24 \cdot 10^{-5} \mathrm{~K}^{-1}$. Wykruszanie składników zachodzi natomiast wyraźnie łatwiej w granitach: G603, Sunny Desert, Queen Yellow, Strzegom, Padang Dark, Grey Super Dark i Queen Brown, które zawierają znaczne ilości kwarcu, o wartości współczynnika ponad dwukrotnie większej $\left(\omega=4,98 \cdot 10^{-5} \mathrm{~K}^{-1}\right)$ niż posiadają plagioklazy oraz ponad trzykrotnie przewyższającej wartość tego parametru wykazywaną przez skalenie potasowe.

Z punktu widzenia trwałości użytkowania elementu kamiennego istotne znaczenie mają spękania „katetalne”, obecne w zewnętrznych fragmentach płyt, oraz spękania znajdujące się w strefie kamienia znajdującej się poniżej obszaru poddanego termicznej obróbce, a będące efektem działania naprężeń rozciągających. Ich obecność, zauważalna głównie w labradorycie Volga Blue oraz w granicie Baltic Brown, może mieć wpływ na pogorszenie fizyczno-mechanicznych właściwości skały, np. mrozoodporności, ścieralności lub wytrzymałości na ściskanie i zginanie.

Autorzy składają podziękowanie Recenzentom oraz Redakcji Przeglądu Geologicznego za poświęcony czas oraz cenne uwagi dotyczące treści artykułu i jego formy. Praca finansowana z funduszu badań statutowych WGGiOŚ AGH, nr 11.11.140.161.

\section{LITERATURA}

BOBROV O.B., GURSKIY D.S., KRASNOZHON M.D., MALYUK B.I., SUKACH V. 2002 - Main Types of Rock Complexes and Mineral Deposits in the Ukrainian Shield. Geological excursion guidebook. Geographica: 1-166.

COOPER H.W, SIMMONS G. 1977 - The effect of cracks on the thermal expansion of rocks. Earth Planet. Sci. Lett., 36 (3): 404-412.

DEENY S., STRATFORD T., DHAKAL R., MOSS P., BUCHANAN A. 2009 - Spalling of Concrete: Implications for Structural Performance in
Fire. In Proceedings of the International Conference Applications of Structural Fire Engineering: 202-207.

GERMANOVICH L.N. 1997 - Thermal Spalling of Rocks, $9^{\text {th }}$ International Conference on Fracture, Sydney, Australia: 2771-2782.

HARMA P., SELONEN O., LUODES H. 2014 - The Wyborg Granite

Batholith-The Main Production Area for Granite in Finland. Eng. Geol. Soc. Territor., 5: 259-262.

HOMAND-ETIENNE F., HOUPERT R. 1989 - Thermally induced microcracking in granites: characterization and analysis. Inter. J. Rock Mech. Min. Sci., 26 (2): 125-134.

HUOTARI T., KUKKONEN I. 2004 - Thermal Expansion Properties of Rock: Literature Survey and Estimation of Thermal Expansion Coefficient for Olkiluoto Mica Gneiss. Working Report, Olkiluoto: 1-63.

KALINOWSKI Z. 2003 - Płomieniowanie - żywioł pracy. Świat Kamienia, 22: 52-56.

KOWALSKI J.S. 2004 - Przemiany temperaturowe kwarcu zjawiskiem wpływającym na powstawanie powierzchniowych wad odlewów. Archiwum Odlewnictwa, 4 (13): 133-138.

KRAVCHENKO S.N. 2005 - First estimate for the age of a mesoproterozoic palaeomagnetic pole from the Volodarsk-Volynsky Massif, the Ukrainian Shield. Stud. Geophys. Geodaet., 49 (2): 177-190.

MAJCHERCZYK T. 1989 - Badanie fizycznych własności skał. Wyd. AGH, Kraków: 1-208.

MISRA P. 2012 - Geology of Chikmagalur, Dharwar Craton, Karnataka. Field Training Report. Department of Earth Sciences, Pondicherry University: 6-11.

PN-EN 12670 : 2002 Kamień naturalny. Terminologia. Polski Komitet Normalizacyjny, Warszawa, 2002.

RAUENZAHN R.M., TESTER J.W. 1989 - Rock Failure Mechanisms of Flame-Jet Thermal Spallation Drilling - Theory and Experimental Testing. Inter. J. Rock Mech. Min. Sci., 26: 381-399.

ROBERTSON E.C. 1988 - Thermal Properties of Rock. United States Department of The Interior, Geological Survey, Open File Rept., 88-441: $1-106$.

SAGONG M., BOBET A. 2002 - Coalescence of Multiple Flaws in a Rock-model Material in Uniaxial Compression. Inter. J. Rock Mech. Min. Sci., 39 (2): 229-241.

STAROSELSKY A. 2005 - Damage and Cracking Morphology. [W: Varvani-Farahani (red.), Advances in Fatigue, Fracture and Damage Assessment of Materials (Advances in Damage Mechanics). WIT Press/ Computational Mechanics: 1-520.

STAROSELSKY A.V., CHIRKOV S.E., SHOBOLOVA L.P., EDELSHTEIN O.A. 1990 - The Influence of Surface Active Substances on Crack Resistance of Hard Rocks. Soviet Min. Sci., 5: 32-35.

WALSH S.D.C., LOMOV I., ROBERTS J.J. 2011 - Geomechanical Modeling for Thermal Spallation Drilling. Geothermal Resources Council $35^{\text {th }}$ Annual Meeting, San Diego. Transactions, 35: 277-282.

ZHAO J.L., QIU J.S., LIU L., WANG R.Q. 2015 - Geochronological, geochemical and Nd-Hf isotopic constraints on the petrogenesis of Late Cretaceous A-type granites from southeastern coast of Fujian Province, South China. J. Asian Sci., 105: 338-359. 